\title{
Impact of Right Bank Outfall Drain-I (RBOD-I) / Main Nara Valley Drain (MNVD) on Manchar Lake, Sindh, Pakistan
}

\author{
Ali Asghar Mahessar \\ Sindh Barrages Improvement Project
Irrigation Department
Government of Sindh
Sindh, Pakistan
}

Shafi Muhammad Kori

Department of Civil Engineering

Mehran University of Engineering and

Technology, Jamshoro, Pakistan

\author{
Kamran Ansari \\ U.S.-Pakistan Center for Advanced \\ Studies in Water, Mehran University of \\ Engineering and Technology \\ Jamshoro, Pakistan \\ Sumera Qureshi \\ Dr. M. A. Kazi Institute of Chemistry \\ University of Sindh \\ Jamshoro, Pakistan
}

\author{
Ghulam Murtaza Arain \\ Pakistan Council for Research of Water \\ Resources, Ministry of Science and \\ Technology, Karachi, Sindh, Pakistan \\ Islamabad, Pakistan \\ Abdul Latif Qureshi \\ U.S.-Pakistan Center for Advanced \\ Studies in Water, Mehran University of \\ Engineering and Technology, Pakistan
}

\begin{abstract}
The lakes of Sindh are in poor environmental condition due to the massive disposal of effluents. This paper presents the impact of water quality in Manchar Lake due to climate change and anthropogenic intervention. The lake is one of the biggest natural lakes in Sindh, Pakistan. The lake has three major sources of water supply: Indus River, hill torrents from the Khirthar Mountain range and the Right Bank Outfall Drain (RBOD-I)/Main Nara Valley Drain (MNVD). The water supply of the lake from the first two sources has been reduced due to morphological and climate changes. Hence, there is only one, and polluted, water supply to the lake, the RBOD-I/MNVD. At the same time, the use of poisonous materials for fishing has further contaminated the lake's water. The RBOD system is connected with RBOD-III, RBOD-I/MNVD, Indus Link and RBOD-II on the right side of Indus River for safe disposal of wastewater into the Arabian Sea, which is still not functioning. Hence, more than 4500 cusecs of wastewater from the catchment area of RBOD have directly been discharged into the lake causing severe impact on flora, fauna and the livelihood of locals. In order to analyze the lake water quality impact, the water quality index (WQI) model was used. The results indicate that the water quality of four samples was very poor, while the fifth sample was unsuitable for drinking. The results of statistical analysis of parameters such as TDS, EC, SO4, Cl, Na, and hardness are higher to their permissible limits. Consequently, lake water possesses a high potential risk to local consumers and aquatic ecology.
\end{abstract}

Keywords-Manchar lake; degradation; RBOD system; Indus river; hill torrent; ecology; drinking freshwater supply; fishermen; locals

\section{INTRODUCTION}

Lakes are natural water bodies that serve as sources of recharging groundwater reservoirs while improving its quality, but unfortunately have significantly been degraded due to growing population and economic development. These lakes are natural water providers, flood storages, natural habitats and breeding homes for indigenous and migratory birds including endangered species. There are 225 sites of wetlands covering an area of about $9.7 \%$ of Pakistan [1]. They are broadly categorized as mountainous lakes, tropical freshwater and salt lakes, Indus River, coastal wetlands and manmade reservoirs [2], but only 46 of them are listed as protected areas including 19 Ramsar sites which have international importance [3]. The covered area of lakes in Sindh is 78,000 hectares. Some important lakes in Sindh include Manachar, Hamal, Keenjhar, Haleji, Hadero, Drigh, Pugri, Langh, Shakoor, Sonhari, Sadhari, Phusna, Charwo, Khanjo, Ghauspur/Sindh Dhoro, Nara Canal area, Narri, Mehro, Sanhro, Pateji, Khipro, Tando Bagho, Mehboob Shah, Shah Bunder/Jaferi, Chotiari reservoir/lake and Hub reservoir. Sindh holds the privilege of hosting Wildlife Protected Ramsar sites as they serve as sanctuaries for waterfowl migratory and local birds such as Keenjhar Lake (Ramsar Site No. 99), Haleji Lake, (Ramsar Site No. 101), Drigh Lake (Ramsar Site No. 100), Jubho Lagoon (Ramsar Site No.1067), and Narri lagoon and Guddu to Sukkur stretch of Indus river (Ramsar sites). These lakes are almost under threat due to fresh water scarcity, less drainage, less rainfall, polluted water, increased sedimentation and eutrophication [4]. The lakes possess ecological value, especially for endangered species [5], and are natural reservoirs for rainwater harvesting, storing floodwater, recharge groundwater and water supplying sources [6]. Entering River flows into the lakes regulating the level of sedimentation and nutrients which affect water quality and quantity [7]. The decline of freshwater quantity and quality alters the ecological ecosystem of the lakes [8]. A major cause of water quality degradation is also the disposal of effluents from agricultural, industrial, and municipal leachates into the lake $[9,10]$. Manchar Lake, which is the biggest lake of Sindh, was developed along with Himalaya, Karakorum and Khirthar

Corresponding author: Ali Asghar Mahessar (amahessar@yahoo.com) 
during the movement of Eurasian tectonic plates. It has been getting millions of tons of sediments with torrential rainwater from Hill torrents of Bolan and Khirthar and Indus River [11]. Now, it has turned into a shallow lake with an average depth of 0.5 to $3.75 \mathrm{~m}$. The lake had initially two natural sources of water supply, hill torrents from Khirther range and inundation canals from Indus River. A third source of Main Nara Valley Drain (MNVD) was also added in 1932. The release of water after the construction of MNVD into the lake started to degrade water quality. Some studies regarding the water quality of Manchar lake have been conducted [12] to assess its physicochemical properties and heavy metal concentrations which were found to be beyond the permissible limits [13]. Moreover, high concentration accumulated sediment was oberved and analyzed. The sources of heavy metals entering the lake are soil erosions, rock weathering and anthropogenic activities on its watershed [14]. Persistent Organic Pollutants (POPs) tend to persist in the environment for long periods, are distributed worldwide, accumulate in the lipids of humans and animals and also bind to sediment [15]. Significant amounts of DDT and coliform were found in the MNVD and the water body of Manchar lake which is now unfit for human consumption [16]. This lake supports the livelihood of half a million locals through fishing and farming. Thousands of the local Mohana (fishermen) have built their boat villages in the lake [17]. Decades of draining untreated domestic, industrial, and agricultural wastewater have polluted the lake [18], which once was a home for Siberian birds from Central Asia [19]. The annual fish catch has also reduced from 2300 tons to 400 tons, while fish species have diminished from 200 to 14 since 1930. Hence, the Siberian birds no longer stop during their annual migration due to insufficient fish availability [20]. The fresh water of Manchar Lake was used for domestic and agricultural purposes by the local communities because the groundwater is unfit for drinking and domestic use [21]. However, the completion of RBOD project, in which the effluents will bypass the Lake and will ultimately get discharged into the sea, will generate series of positive impacts such as improving socio-economic and environmental conditions and reclaiming degraded lands and improving the quality of the lake [22, 23]. Hence, the significance of the lake will be revived. The main aim of the present study is to have a thorough physicochemical analysis of the Manchar Lake water to ascertain the impact of RBOD/MNVD on its quality.

\section{STUDY AREA}

The Manchar Lake is located at $26^{\circ} 27^{\prime} 21^{\prime \prime}$ latitude and $67^{\circ} 38^{\prime} 31^{\prime \prime}$ longitude. It is the biggest natural shallow lake of Sindh, Pakistan, situated at a distance of about $18 \mathrm{~km}$ from Sehwan Sharif city in Jamshoro district. It is a vast natural depression flanked by the Khirthar hills in the west, Laki hills in the south and River Indus in the east. It is a shallow saucer shaped basin and the area of the lake varies depending on the influx of water. On northern and eastern side, an earthen embankment was constructed, the Manchar containing bank of $36 \mathrm{~km}$ length. Historically, the lake was filled by the hill torrents and flood spills of the Indus River. MNVD (Figure1) is also one of its main, and more recent, sources. The area of the lake reduces during the winter season but it extends and its depth increases during monsoon season. It is a regular practice to feed the Manchar Lake during monsoon season from River Indus through Danister wah, Aral Head Regulator and Aral Tail Regulator, and by torrential water coming from the Khirthar mountain range. Besides this, it is depleted by draining out water into River Indus through the Aral Tail Regulator before the arrival of the monsoon season to maintain its safety level RL $100 \mathrm{ft}$. The climate of the study area is arid. There is a seasonal variation of weather conditions such as temperature, pressure, humidity, evaporation, evapotranspiration, and precipitation. The maximum, average and minimum temperature is $48^{\circ} \mathrm{C}, 40^{\circ} \mathrm{C}$ and $35^{\circ} \mathrm{C}$ in summer season while it is $26^{\circ} \mathrm{C}, 22^{\circ} \mathrm{C}$ and $16^{\circ} \mathrm{C}$ in winter season, respectively. The maximum humidity has been observed in July and August and the minimum in October and May. The high and low observed pressure is 1018 and $995 \mathrm{mb}$ in January and July respectively and the evaporation varies from 10 to $15 \%$.

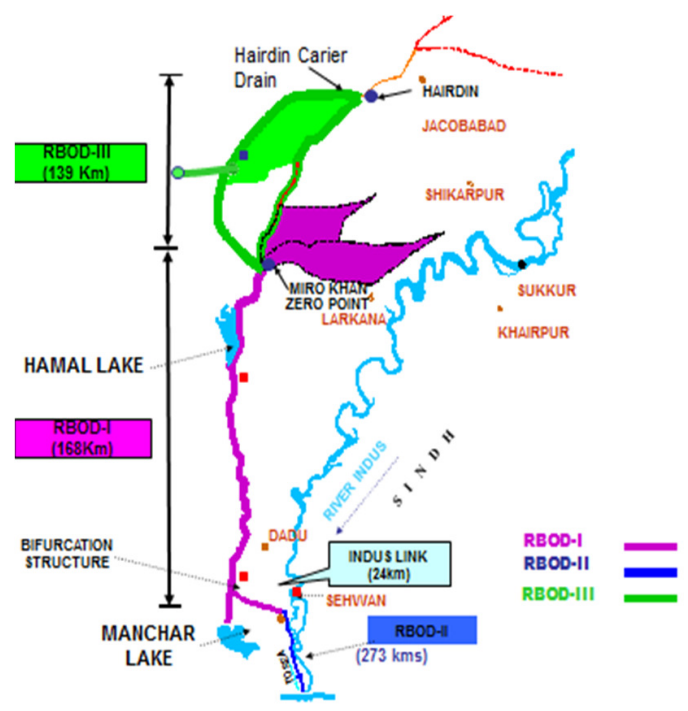

Fig. 1. Layout plan of RBOD-I, III and II

\section{MATERIALS AND METHODS}

A walkthrough survey was carried out regarding the water quantity and quality of Manchar Lake assessment. There are three major feeding sources to the Lake: 1) hill Torrents from Khirthar range, 2) MNVD, and 3) Indus River through Aral wah and Danister wah (two natural canals). The draining of the lake is done through the Aral tail wah into Indus River. The lake is shallow, its depth varies from $0.5-3.5 \mathrm{~m}$ and its bed level is about $5 \mathrm{~m}$ lower than Indus river bed. Hence, the covering area varies seasonally from 140 to $200 \mathrm{~km}^{2}$. There is limited eutrophication, and aquatic vegetation in the inner side of the lake, bad odor and greenish water color were observed due to low fresh water flow. Sediment deposition is common practice which has reduced the storage capacity of the lake. The existing estimated annual inflows to Manchar Lake are shown in Table I from various sources with total volume 0.899MAF. The evaporation of Manchar Lake is calculated as 0.189MAF, hence the store capacity of the lake would be $0.329 \mathrm{MAF}$. 
TABLE I. ESTIMATION OF INFLOWS TO MANCHAR LAKE

\begin{tabular}{|c|c|}
\hline Water supply source & Volume (MAF) \\
\hline Hill torrents & 0.133 \\
\hline Nai Gaj & 0.188 \\
\hline Indus River & 0.053 \\
\hline MNVD & 0.525 \\
\hline Total & 0.899 \\
\hline Evaporation loss & 0.189 \\
\hline Net inflows & 0.710 \\
\hline
\end{tabular}

(a)

(b)

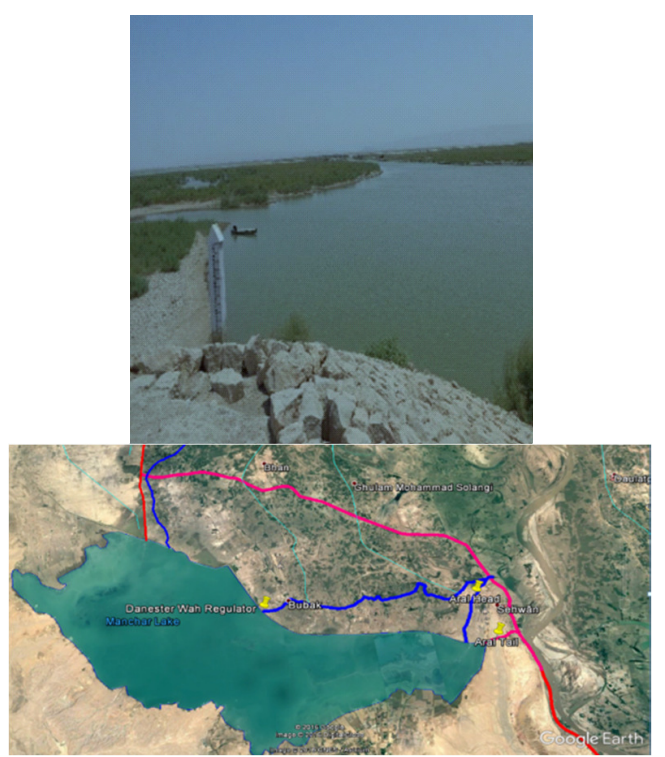

Fig. 2. Water level gauge installed at Manchar Lake, (b) Covered water body of Manchar lake. Screenshot from Google Earth, (C) 2019 Google, Image (C) 2019 Maxar Technologies, Image (C) 2019 CNES/Airubus

Water samples were collected from MNVD, the water body of the Lake, and the Aral tail wah for physicochemical and heavy metal analysis. The $\mathrm{pH}$ and TDS values of collected samples were measured in situ. Moreover, the collected water samples were preserved with Nitric Acid in an ice box for maintaining low temperature and were sent to Hi-tech Laboratory, Sindh University, Pakistan for analysis. Samples have been collected from the following locations:

- Sample 1 (S-1): RBOD-I/ MNVD RD-250, at latitude $25^{\circ} 30^{\prime} 38^{\prime \prime}$ and longitude 67'37'29',

- Sample-2 (S-2): Western hill side, at latitude 26²6’23", and longitude $67^{\circ} 35^{\prime} 29^{\prime \prime}$

- Sample 3 (S-3): Lakhi hill side, at latitude $26^{\circ} 26^{\prime} 14^{\prime \prime}$ ' and longitude $67^{\circ} 45^{\prime}, 50^{\prime}$ '

- Sample 4 (S-4): Center of Lake, at latitude $26^{\circ} 25^{\prime} 39^{\prime \prime}$ and longitude $67^{\circ} 37^{\prime} 19^{\prime}$ '

- Sample 5 (S-5): Aral tail wah, at latitude 26²4'10’' and longitude 6751'49',

It was observed that the fertility of the agricultural land has been degraded due to the presence of saline water and seepage. The water quality is such that it is unfit for drinking and not usable for agriculture practice, but the locals are using it anyway, because they have no other option.

\section{RESULTS AND DISCUSSION}

\section{A. Indus River Aral Head Regulator}

The design discharge of Aral Head Regulator is 10,000 cusecs taken from Indus, when the downstream of Sukkur Barrage discharge exceeds 250,000 cusecs. The design discharge of Aral tail regulator is 25,000 cusecs which is the main source of draining of the Lake into Indus when Indus is at normal flow and the designed discharge of Danister canal is 500 cusecs which is located at RD 62 of Manchar Containing Bank. Figure 3(b) shows the capacity of the lake in million cubic feet (MCFT) and area in square miles.

(a)

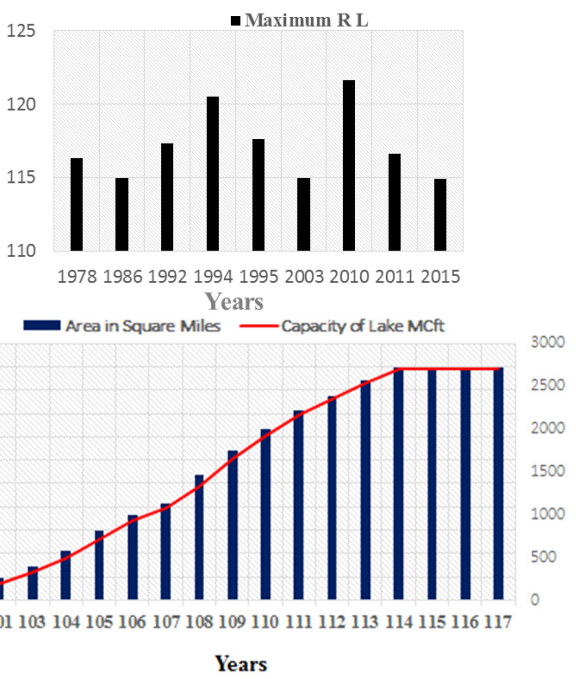

Fig. 3. (a) Water level gauge installed at the Lake, (b) Lake storage capacity against areea

\section{B. Physicochemical Analysis}

Figure 4(a) shows the $\mathrm{pH}$ and Total Dissolved Solids (TDS) values of the collected samples. The $\mathrm{pH}$ is a measure of water acidity and values from 6.5 to 8.5 are suitable for aquatic life. The $\mathrm{pH}$ values of all samples varied between 7.5 and 8 and were within the permissible limits according to the National Environmental Quality Standards (NEQS). The TDS of the collected samples were above the permissible (1000ppm) limit of NEQS. The TDS value of S-1 was found higher than the other samples because MNVD receives highly salt concentration water through RBOD-III. The TDS of the other samples varies due to dilution. Therefore, the water from MNVD and from the lake is unfit for drinking, agricultural practice, or fishing. The NEQS permissible limits of Biochemical Oxygen Demand (BOD) and of Chemical Oxygen Demand (COD) are $80 \mathrm{mg} / \mathrm{L}$ and $150 \mathrm{mg} / \mathrm{L}$ respectively. Figure 4(b) shows that the BOD and COD values of the samples are within these permissible limits. The conclusion is that there is no danger for the aquatic life regarding oxygen demand. Ca and $\mathrm{Mg}$ salts inhibit the formation of soapsuds. Figure 5(a) shows the hardness values of the samples witch are all found higher than the permissible limit $(500 \mathrm{ppm})$. The sample values of Calcium are within the permissible limit (200ppm). Figure 5(b) shows the values of $\mathrm{Mg}$ and $\mathrm{Na}$ which are higher than their respected permissible limits (150ppm and 200ppm). 


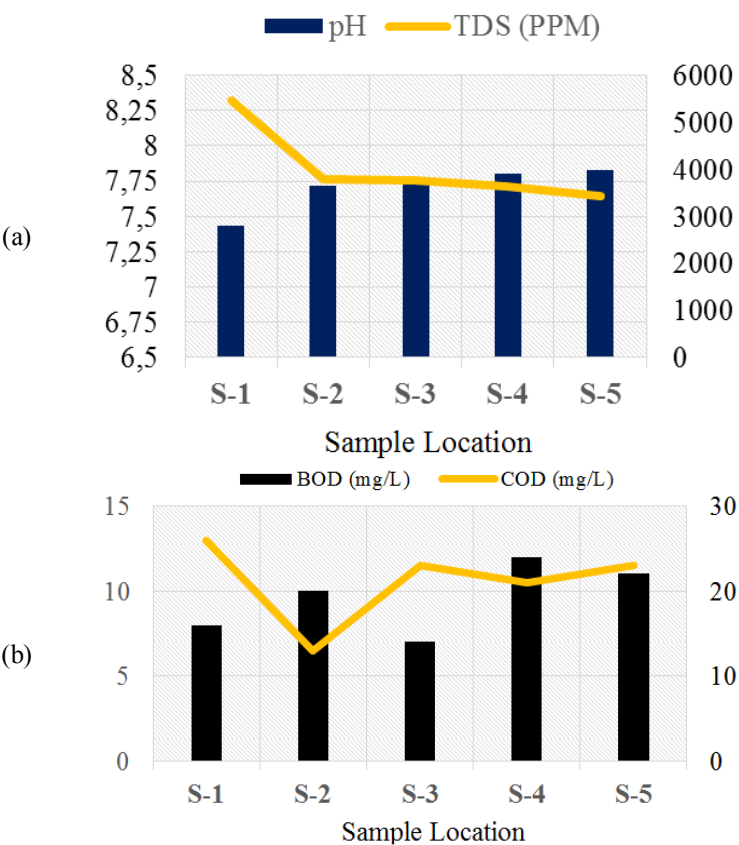

Fig. 4. (a) $\mathrm{pH}$ and TDS values, (b) BOD and COD values

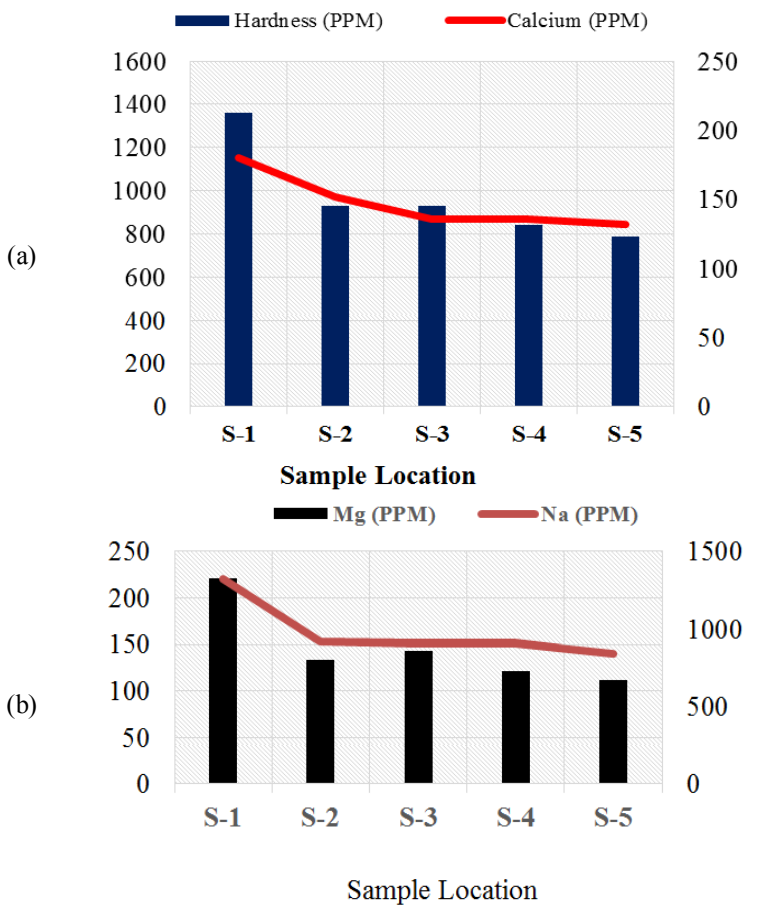

Fig. 5. (a) Hardness and calcium values, (b) $\mathrm{Mg}$ and $\mathrm{Na}$

The permissible limits of $\mathrm{SO}_{4}$ and $\mathrm{Cl}$ are 250ppm and 250ppm. The values of all collected samples (Figure 6(a)) are higher than these limits. The higher $\mathrm{SO}_{4}$ concentration of all samples is caused by the releasing of agricultural, industrial, and municipal wastewater through ROBD-I/MNVD into the lake. Figure 6(b) shows the Total Coliform of the samples which is higher than the permissible limit which is $0 \mathrm{mg} / \mathrm{L}$.
We can conclude that the importance of the lake is reduced due to the degradation of water quality, which is now unfit for human consumption, local flora and fauna or any other use.

(a)
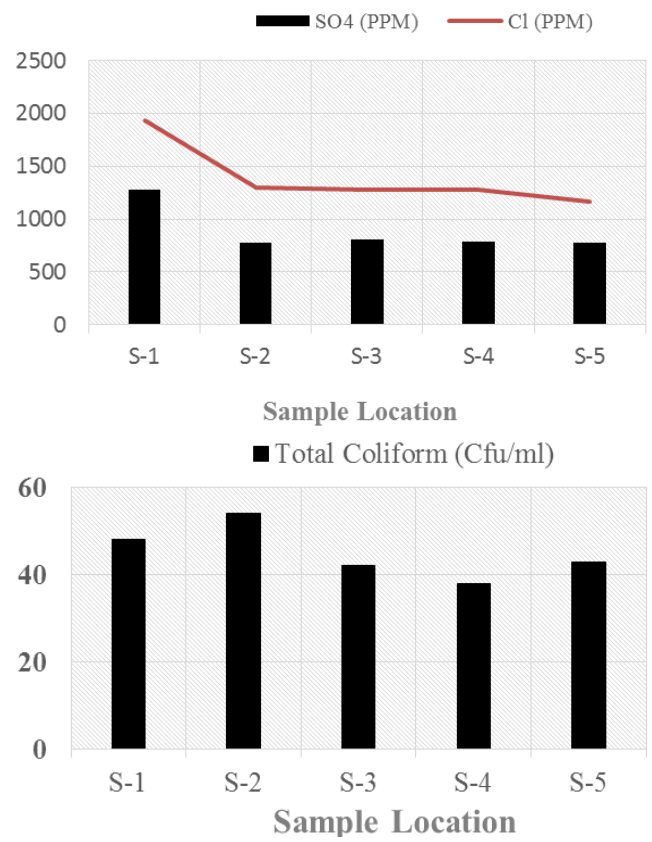

Fig. 6. (a) Sulphate and chloride values of samples, (b) Total Coliform values

\section{Water Quality Index}

Water Quality Index (WQI) indicates the overall water quality based on the parameters of water quality samples. WQI is computed by:

$$
Q W I=\sum_{n-1}^{n} W i \times Q i
$$

where $Q i$ is the sub-index for the $i$ th WQ parameter, $W i$ is the weight associated with the $i$ th WQ parameter, and $n$ is the total number of WQ parameters.

WQI is an indicator to assess water quality suitability of surface/groundwater for domestic and drinking purposes and surmises many parameters of water samples [24]. The WQI standards are shown in Table II. Figure 7 shows the WQI values of the five analyzed samples. The values of S-1 to S-4 were found in range of 75-100 of WQI which indicates very poor water quality, while S-5 was found to be even worse and unsuitable for drinking. This study exhibits that contamination with TDS, EC, SO4, Cl, Na and hardness in the lake water poses high potential risk to the locals, especially those who use it as drinking water.

TABLE II. SURFACE WATER RATING BASED ON WQI

\begin{tabular}{|l|c|}
\hline \multicolumn{1}{|c|}{ QWI value } & Water quality rating \\
\hline $0-25$ & Excellent \\
\hline $25-50$ & Good \\
\hline $50-75$ & Poor \\
\hline $75-100$ & Very poor \\
\hline$>100$ & Unsuitable for drinking purposes \\
\hline
\end{tabular}




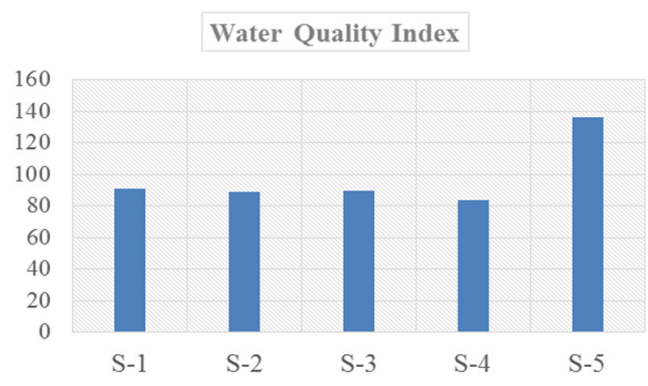

Fig. 7. WQI of Manchar Lake water (drinking water)

\section{Impairment of Aquatic and Terrestrial Lake Ecosystem}

The major issues related to the degradation of the Lake are the reduced supply of freshwater due to rainfall runoff reduction from the Khirthar range, the high discharge of contaminated water from the MNVD and the lack of freshwater supply from Indus River. There are various other sources of pollution such as chemical sediments from hill torrents, pollutants from cities, industries, and agricultural lands through MNVD/RBOD-I via RBOD-III, sedimentation from Indus River through Aral head wah and poisonous chemicals used by fishermen. The climate change causes dry spells, less water is carried by Indus River, the water requirement for agriculture is inevitably higher, and industries and urbanized population lead to polluted inflows having negative impact on the ecology of the lake.

\section{1) Poor Lake Water Quality}

The water quality of the water body is very poor. The analysed values of collected samples' parameters calcium, hardness, chlorine, manganese and sulphate of MNVD and lake water are much higher than their permissible limits. Despite this, the locals are using contaminated lake water because the groundwater around the lake is highly saline.

\section{2) Degraded Groundwater Quality}

The lake is covered with mountain ranges from the western and eastern sides, but the southern side consists of alluvial soil. The groundwater quality has been degraded due to seepage of saline water from the lake and the groundwater table has been raised due to the twin problem of waterlogging and salinity. Hence, the groundwater is unfit for drinking, agriculture, or any other purpose.

\section{3) Social Value of Manchar Lake}

Manchar is exclusively known for its "floating villages" where more than 1000 fishermen reside with their families. The population in surroundings and within the lake numbers in many thousands. The locals' main occupations are farming, fishing, and tendering cattle. The living standards have been reduced because almost all the locals' survival sources have diminished.

\section{4) Impact on Health}

The consumption of degraded water by the locals who live in boat villages and around the lake caused the emergence of endemic waterborne diseases including gastroenteritis, malaria, asthma, hepatitis A, B and C, diarrhea, tuberculosis, respiratory diseases, typhoid fever, etc.

\section{5) Impact on Fishing}

Fish species including Chitla (Guddan), Gibleon Catla Catla (Thaili), Labeo Rohita (Rohu or Dumbra), Labeo Calbasu (Balck Rohu), wallago catfish (Jarko), white carp (Morakho), rita rita (Khagga) and Aorichthyas (Seenghari) used to be abundant. Now, all fish are extinct but a small exotic fish variety is available which can survive in saline and polluted water. Hence, the fish catch is reduced and the average catch by an individual which used to be $30-40 \mathrm{~kg} /$ day in 1970 , now it is about $4-5 \mathrm{~kg} / \mathrm{day}$.

\section{6) Impact on Fertile Land}

The fertile lands in the adjacent area of the lake do not get water from the irrigation system because this area is at the tail of the command area of Dadu canal which intakes from Sukkur barrage. Therefore, there is a common practice of application of water from MNVD and the lake for growing crops and vegetation. This continuous practice of contaminated water use has severely affected soil fertility. The once fertile soil has been converted to saline and sodic which has reduced crop yield. It is feared that further use of this practice may convert fertile lands to unproductive lands for any crop.

\section{7) Impact on Livestock}

Livestock was the main source of milk, mutton, meat, and income. Therefore, each household has buffaloes, cows, sheep, and goats. The household cattle use to get their food from the land and pastures nearby the lake, but the pastures have been diminished due to land degradation and waterlogging.

\section{8) Impact of the Construction of the RBOD System}

The natural drainage system took water from Indus at downstream of Guddu barrage which was the source of water supply to Manchar lake via Hamal during monsoon season. This natural drainage had been blocked due to road construction and agricultural land conversion. The RBOD system covers RBOD-III, RBOD-I/MNVD and RBOD-II. The RBOD-III receives wastewater from some parts of Baluchistan and Sindh and is connected with RBOD-I at the zero point of Mirokhan and Shahdadkot drains. RBOD-I/MNVD has been connected with ROBD-II via Indus Link at Manchar CrossRegulator (Figure 1). Hence, the RBOD-II is parallel to Indus River from Sewan to Jamshoro which outfalls into Gharo creek of Arabian Sea. Therefore, there are constructive, negative or complex impacts of RBOD on the Manchar. At present time, about 4500 cusecs of wastewater from industries, municipalities, and agriculture are directly disposed to the lake through the RBOD-I/MNVD because the RBOD-II is under construction. With the diversion of RBOD-I/MNVD from lake to RBOD-II, the major pollutant source will be stopped but it may diminish the volume of lake water. The major sources of water supply (Indus River, hill torrents from Khirthar) have already been reduced. After the diversion of RBOD-I/MNVD water, the lake may convert into a small pond which will be the end of its aquatic and terrestrial ecosystem.

The overall impact of the system consists of safe wastewater disposal, rainfall runoff, waterlogging and salinity reduction, change in land use and capability, the reclamation of 
saline and sodic soils, and the improvement of groundwater quality.

\section{CONCLUSIONS}

The results of WQI indicate that the water quality of the collected samples is very poor and unsuitable for drinking. Statistical analysis of parameters such as TDS, EC, SO4, Cl, $\mathrm{Na}$ and hardness shows that they are higher than their permissible limits. Consequently, lake water possesses high potential risk to local consumers and especially aquatic life. The estimated lake water supply quantity is 0.899 MAF from major sources such as Indus River, hill torrents, and MNVD but these supply sources are gradually diminishing, which threatens the lake's very existence. Therefore, the restoration of these sources of water supply should be a priority. The construction of river weir/barrage at Sewan may raise water level to divert into the lake, the downstream inflow from the under construction of Nai Gaj dam must be ensured. Sindh local government plans to restore the lake with additional supply of freshwater from the Rice and Dadu canals. These canals may supply fresh water into lake and address the problem of pollution. The RBOD II project was to be completed earlier but the task could not be accomplished timely due to insufficient funds. The RBOD-II project must be accomplished on a priority basis for diverting contaminated water from lake towards the Arabian Sea. Besides this, there is a need to address the contamination of the lake by poisonous chemicals which have degraded the local ecology. Moreover, a management and restoration of Manchar Lake plan should be developed through an Integrated Water Resources Management under Sindh Irrigation Department with other stakeholders such as the Sindh Environmental Protection Agency, the Agriculture, Forests and Wildlife, and Livestock and Fishery Departments and the Local Government. These agencies must work together on the Lake Management Program, to form a Legal Framework for Lakes, to address drainage issues, to improve water quantity and quality, to restore ecology, to enhance ecotourism, and to conduct research studies to integrate scientific and engineering solutions for the system's sustainability.

\section{REFERENCES}

[1] M. Z. Khan, D. Abbas, S. A. Ghalib, R. Yasmeen, S. Siddiqui, M. Nazia, A. V. Latif, "Effects of environmental pollution on aquatic vertebrates and inventories of Haleji and Keenjhar Lakes: Ramsar Sites", Canadian Journal of Pure and Applied Scieces, Vol. 6, No. 1, pp. 1759-1783, 2012

[2] A. K. Asad, A. Sana, "Wetlands of Pakistan: distribution, degradation and management", Pakistan Geographical Review, Vol. 69, No. 10, pp. 28-45, 2014

[3] A. L. Rao, Protection and management of Pakistan wetlands midterm review, Ministry of Environment, Pakistan, 2009

[4] A. A. Mahessar, A. L. Qureshi, K. C. Mukwana, A. Q. Jakhrani, "Study of environmental impacts and threats to the Ramsar Haleji Lake, Sindh, Pakistan", International Journal of Applied Environmental Sciences, Vol. 10, No. 5, pp. 1577-1590, 2015

[5] W. J. Mitsch, J. G. Gosselink, "The value of wetlands: importance of scale and landscape setting”, Ecological Economics, Vol. 35, No. 1, pp. 25-33, 2000

[6] B. Fisher, K. Turner, M. Zylstra, R. Brouwer, R. de Groot, S. Farber, P. Ferraro, R. Green, D. Hadley, J. Harflow, P. Jefferiss, C. Kirkby, S. Mowatt, R. Naidoo, J. Paavola, B. Strassburg, D. Yu, A. Balmford, "Ecosystem services and economic theory: integration for policy- relevant research", Ecological Applications, Vol. 18, No. 8, pp. 20502067, 2008

[7] P. G. Whitehead, R. L. Wilby, R. W. Battarbee, M. Kernan, A. J. Wade, "A review of the potential impacts of climate change on surface water quality”, Hydrological Sciences Journal, Vol. 54, No. 1, pp. 101-123, 2009

[8] P. S. Lake, "Ecological effects of perturbation by drought in flowing waters", Freshwater Biology, Vol. 48, No. 7, pp. 1161-1172, 2003

[9] A. Q. Jakhrani, S. R. Samo, I. Nizamani, "Impact of wastewater effluents on physico-chemical properties of groundwater", Sindh University Research Journal (Science Series), Vol. 41, No. 1, pp. 75-82, 2009

[10] A. Q. Jakhrani, Impact of oxidation ponds on groundwater quality at Hyderabad, ME Thesis, Mehran University of Engineering and Technology, Jamshoro, 2002

[11] S. H. Wadho, Geological conditions of River Indus and floods in Sindh, Sindhica Academy, 2019

[12] M. B. Arain, T. G. Kazi, M. K. Jamali, H. I. Afridi, J. A. Baig, N. Jalbani, A. Q. Shah, "Evaluation of physic-chemical parameters of Manchar lake water and their comparison with other global published values", Pakistan Journal of Analytical \& Environmental Chemistry, Vol. 9, No. 2, pp. 1010-109, 2008

[13] W. M. Achakzai, S. Saddozaai, W. A. Baloch, Samiullah, M. A. Panezai, Z. Masood, A. N. Somroo, "Comparison of water chemistry of Manchar lake with WHO drinking water quality standards", AmericanEurasian Journal of Agricultural and Environmental Sciences, Vol. 15, No. 7, pp. 1224-1230, 2015

[14] T. M. Jahangir, M. Y. Khuhawar, S. M. Leghari, M. T. Mahar, K. P. Mahar, "Water quality and sediment assessment of Manachar lake, Sindh Pakistan: after effects of the super floods of 2010", Arabian Journal of Geosciences, Vol. 8, pp. 3259-3283, 2015

[15] Y. H. Kang, G. Y. Sheng, J. M. Fu, B. X. Mai, G. Zhang, Z. Lin, Y. S. Min, "Polychlorinated river delta and Macau", Marine Pollution Bulletin, Vol. 40, No. 9, pp. 794-797, 2000

[16] Z. A. Soomro, M. Ashrif, U. Imran, J. Wu, Environmental assessment of Manchar Lake, Pakistan Council of Research in Water Resource, 2017

[17] Indus for All Programme, WWF - Pakistan, Ecological assessment of fauna, at Manchar lake, district Dadu, Sindh, 2001-2011

[18] N. Anial, "Mohannas of Manchar lake Sindh: an indigenous culture tradation pushed to the edge", THAAP Journal, Vol. 2015, pp. 97-118, 2015

[19] A. Sheeba, S. Bano, J. H. Kazmi, "Moniotring spatial distribution of the selected bird's species in wetlands of Sindg: a framework of remote sensing and GIS", International Journal of Biology and Biotechnology, Vol. 10, No. 1, pp. 7-20, 20013

[20] S. M. Zehra, Time series models of the electrical conductivity at the Manchar Lake in Pakistan, MSc Thesis, The University of Texas at Austin, 2010

[21] T. M. Jahangir, Chemical assessment of surface and groundwater resources of Sindh province, PhD Thesis, University of Sindh, 2004

[22] A. A. Mahessar, K. C. Mukwana, A. L. Qureshi, M. E. ul H. Leghari, A. L. Manganhar, "Assessment of water quality of LBOD system and environmental concerns", Quaid-E-Awam University Research Journal of Engineering, Science \& Technology, Vol. 15, No. 1, pp. 32-39, 2016

[23] A. A. Mahessar, A. L. Qureshi, A. N. Leghari, S. Qureshi, S. F. Shah, F. A. Shaikh, "Impact of Hairdin, Miro Khan and Shahdad Kot Drainage on Hamal Dhand, Sindh", Engineering, Technology \& Applied Science Research, Vol. 8, No. 6, pp. 3652-3656, 2018

[24] N. B. Bhatti, A. A. Siyal, A. L. Qureshi, "Groundwater quality assessment using water quality index: a case study of Nagarparkar, Sindh, Pakistan", Sindh University Research Journal (Science Series), Vol. 50, pp. 227-234, 2018 